INTERNATIONAL JOURNAL OF MULTidisciplinARY RESEARCH AND ANALYSis

ISSN(print): 2643-9840, ISSN(online): 2643-9875

Volume 04 Issue 02 February 2021

DOI: 10.47191/ijmra/v4-i2-11, Impact Factor: 6.072

Page No.- 172-180

\title{
Evaluation of Microbial and Elemental contaminants of Open Market Sachet Water in Nnewi Metropolis
}

\author{
Ed Nwobodo ${ }^{1}$, Oluchukwu C. Ezeasouba ${ }^{2}$, David Chibuike Ikwuka ${ }^{3}$, Gabriel Ejike Igbokwe ${ }^{4}$, \\ Chinyelu Egwuatu ${ }^{5}$, Kester Eluemunor Nwaefulu ${ }^{6}$ \\ 1,2,3,6 Department of Human Physiology, Faculty of Basic Medical Science, Nnamdi Azikiwe University, Awka, Nigeria \\ ${ }^{4}$ Department of Applied Biochemistry, Faculty of Biosciences, Nnamdi Azikiwe University, Awka, Nigeria \\ ${ }^{5}$ Department of Pure and Industrial Chemistry, Faculty of Physical Sciences, Nnamdi Azikiwe University Awka, Nigeria
}

ABSTRACT: This Study Assessed Microbial And Elemental Constituents Of Sachet Drinking Water In Nnewi Metropolis. 100 Questionnaires Were Administered To Get Responses Of Individuals Who Frequently Drink Sachet Water And Cross-Sectional Study Was Conducted Using 10 Sachet Water Samples Collected From Nnewi. Each Sample Was Subjected To Physicochemical Examinations And Microbiological Examination. Data Were Analyzed Using Descriptive And ANOVA. 29\% Respondents Reported Developing Some Symptoms After Drinking A Particular Brand Or Different Brands. 60\% Of Samples Had Mercury Levels Exceeding The Maximum Contaminant Level Of $0.006 \mathrm{mg} / \mathrm{L}$, While All Samples Had Lead Levels Exceeding Maximum Contaminant Level Of $0.01 \mathrm{mg} / \mathrm{L}$. Microbial Test Revealed Bacterial Contamination In All Brands And Protozoon Contamination In One. Study Concluded That Sachet Water Is Unfit For Drinking Due To High Levels Of Elemental Constituents And Bacterial Contamination. It Therefore, Highlight The Need For Government Agencies To Intensify Surveillance And Enforce Stringent Hygienic Measures To Sachet Water Industries/Retail Outlets.

KEYWORDS: Sachet Water; Water Contamination; Microbial; Lead Poisoning; Mercury; Health Risk

\section{INTRODUCTION}

Water Is The Most Important Natural Resources Required For The Existence Of Man [1] And Access To Safe Drinking Water Is Critical To Human Health And Development. [2] Worldwide, Approximately Three Of The 10 People (2.1 Billion) Do Not Have Access To Safe Drinking Water. [3] In The African Continent, The Majority Of The People Are Living In Environments Where The Available Water Resources Do Not Meet Global Standard. [4]

In Many Sub-Saharan African Cities, Packaged Water Has Emerged As An Alternative Source Of Drinking Water. [5] In Nigeria, Sachet Packaged Drinking Water Was Introduced As A Less Expensive Means Of Accessing Drinking Water Than Bottled Water; [6] This Innovation Replaced The Former Types Of Drinking Water Packaged For Sale To Consumers In Hand Filled, Hand Tied Polyethylene Bags. The Water Is Packaged In Individual Units Of 50 Centiliter High Density Polyethylene Sachets Commonly Referred To As 'Pure Water' In Local Parlance. [7]

Due To Its Affordability And Convenience, There Has Been A Dramatic Increase In The Production And Consumption Of Sachet Water In Nigeria Over The Past Two Decades. These Sachet Waters May Not Be Completely Sterile; And May Also Not Be Entirely Free Of All Infectious Microorganisms And Heavy Metal Contaminants. There Have Been Some Random Reports By Some Individual Of Experiencing Some Reaction Or Symptoms On Consumption Of Sachet Water. Such Reported Reactions Or Symptoms Include Stomach Upset, Nausea, Irritation Of Some Body Parts, Etc. This Raises The Question Of Whether Sachet Waters Are Actually Safe For Human Consumption And Free Of Contaminants. The Danger Linked With Sachet Water Is Contamination, Is A Factor Of The Water Source, Its Treatment, Dispensing Into Sachets And Closure. [7] At The Time Of This Publication, The Authors Do Not Know Of Any Study Investigating The Microbial And Elemental Contaminants In Open Market Sachet Water In Nnewi, Nigeria. Hence, The Objectives Of This Study Were To Analyze The Microbial And Elemental Contaminants Of Open Market Sachet Water. 


\section{Evaluation of Microbial and Elemental contaminants of Open Market Sachet Water in Nnewi Metropolis}

\section{METHODS}

A. Ethical Approval

This Cross-Sectional Study Was Approved By The Faculty Of Basic Medical Sciences Research Ethics Committee, Nnamdi Azikiwe University Nnewi Campus, Nigeria With Protocol Code 071/03/2019.

\section{B. Study Design And Setting}

The Research Took Place In Nnewi, Nigeria, Which Is The Second Largest City In Anambra State In Southeastern Nigeria. Nnewi, A Metropolitan City Is Estimated To Have A Population Of 391,227 According To Nigerian Census And The City Spans Over 1,076.9 Sqm In Anambra State. [8] It Is An Industrial City And Home To The First Indigenous Car Manufacturing Plant In Nigeria And Other Major Industries. Drinking Water Sources In This Community Include Among Others, Sachet Water, Bottled Water, Piped Water, Bore-Hole, Wells And Rivers. However, Due To The Higher Demand For Plastic-Bagged Sachet Water, It Was Chosen For Our Study. There Are Over 15 Sachet Water Brands In Nnewi.

\section{Data And Sample Collection}

Data Collection Was Done Using Human Health And Lifestyle Questionnaire Randomly Distributed To 100 Individuals. HHLQ Is A Researchers' Designed Instrument That Was Validated By Experts And Was Deemed Reliable For The Study.

10 Samples Out Of The 15 Brands Of Sachet Water Were Purposively Purchased From Shops Shelves Within Nnewi. Purposive Sampling Was Employed Based On The Popular Brand Names Commonly Consumed. All The Samples Were Taken To The Laboratory For Both Microbial And Physicochemical Analysis.

\section{Physicochemical Analysis}

Physicochemical Parameters Measured Were: Odour, Colour, And Taste; Calcium, Lead And Mercury. The Odour, Colour And Taste Were Measured Using Method Described By Yakassai. [9] Heavy Metal Analysis Were Performed Using Variant AA240 Atomic Absorption Spectrophotometer (Bioscience UK) As Described By APHA. [10]

\section{E. Microbiological Analysis}

Sachets For Microbiological Analysis Were Aseptically Opened Using Ethanol-Cleaned Scissors. The Samples Were Analyzed For Total Microbial Count, Total Coliforms, Bacterial Isolates, Protozoa And Fungi.

1. Total Microbial Count: Ten-Fold Serial Dilutions Of The Water Samples (Sachet Water) Were Done And Appropriate Dilutions Were Plated On Nutrient Agar (NA) Plates. The Cultured Plates Were Incubated At Room Temperature For 24 Hours For Bacteria. Thereafter, The Developing Colonies Were Counted.

2. Determination Of Total Coliform: This Method Is Used To Determine The Presence Of A Member Of A Coliform Group In Water Sample. 50ml Sachet Water Sample Was Filtered Through A Membrane Filter Which Retains The Bacteria Found In The Sample. In The Two-Step Enrichment Procedure, The Filters Containing Bacteria Were Placed On An Absorbent Pad Saturated With Lactose Broth And Incubated At $35^{\circ} \mathrm{C}+0.5^{\circ} \mathrm{C}$ For $2 \mathrm{Hrs}$. The Filters Were Then Transferred To An Absorbent Pad Saturated With Eosin-Methylene Blue Media And Incubated For Another $21 \mathrm{hrs}$ At $35^{\circ} \mathrm{C}+0.5^{\circ} \mathrm{C}$. Developing Colonies Were Then Counted Under Magnification And Reported Per 100 Ml Of Original Sample.

3. Characterization And Identification Of Bacteria: Identification Of The Bacterial Isolates Was Accomplished By The Observation Of Colonial Characteristics, Gram Reaction And Biochemical Tests. [11] The Characterization Of The Isolates Were Performed, By Employing Gram Staining Reaction, Catalase Test, Citrate Test, Sugar Fermentation Test, Coagulase Test, Motility Test, Indole Test, Methyl Red And Voges-Proskauer Test As Described By Bergey's Manuel Of Determinative Bacteriology $9^{\text {th }} \mathrm{Ed}$. [12]

4. Test For Protozoa: Exactly $20 \mathrm{ml}$ Of Water Samples Were Dispensed In Clean Sterile Glass Test Tubes And Centrifuged At 2500 Rpm. Thereafter, The Supernatants Were Decanted. A Drop Of The Deposit Was Placed On A Clean Grease-Free Glass Slide And A Drop Of Lugol's lodine Was Added And Emulsified. The Slide Was Viewed Using X10 And X40 Objective Lenses Respectively. [13]

5. Test For Fungi: Ten-Fold Serial Dilutions Of The Water Samples (Sachet Water) Were Done And Appropriate Dilutions Were Plated On Sabour Aud Dextrose Agar (SDA) Plates. The Cultured Plates Were Incubated At Room Temperature For 48-72hours. Thereafter, The Developing Colonies Were Counted For The Total Fungal Count.

\section{F. Statistical Analysis}

The Data Obtained In This Study Were Compiled And Analyzed Using Microsoft Excel 2010 (Microsoft Corp. USA) And Statistical Package For Social Science (SPSS Version 20.0). Descriptive Statistics Were Used To Summarize The Results Of The Water Samples. Analysis Of Variance Was Used To Assess The Significance Of Mean Changes Of The Elements. 


\section{Evaluation of Microbial and Elemental contaminants of Open Market Sachet Water in Nnewi Metropolis}

\section{RESULT}

The Results Are Presented In Tables 1 To 5 Below. The Results In Table 1 Showed That 29\% Of Our Human Subjects Reported Developing Some Reactions Or Symptoms Upon Drinking A Particular Brand Or Different Brands Of Sachet Water. One Person Reported Consistent Gastritis Upon Drinking Any Brand Of Sachet Water, Which Results In Hospitalization.

The Aesthetic Quality And The Concentration Of Mercury, Lead And Calcium In Ten Different Samples Of Open Market Sachet Water Are Presented In Table 2 Below. The Result Shows Mercury Concentration Ranging From 0.00mg/L To 7.772mg/L. Six Brands (60\%) Had Their Mercury Level Between 0.655 To 7.772 Mg/L Which Exceeded The Maximum Contaminant Level (MCL) Of $0.006 \mathrm{mg} / \mathrm{L}$ As Set By The WHO. Mercury Was Not Detected In Four Brands (40\%). The Lead Level Ranged From 0.247 To $1.018 \mathrm{mg} / \mathrm{L}$ And Exceeded The Maximum Contaminant Level Of $0.01 \mathrm{mg} / \mathrm{L}$ As Set By The WHO. The Calcium Level Ranged From 0.00 To $0.043 \mathrm{Mg} / \mathrm{L}$, Indicating That All The Sachet Water Analyzed Is Soft Water. All The Open Market Sachet Drinking Waters Analyzed Were Colourless, Odourless And Tasteless.

The Mean Total Bacterial Count Of Each Of The Ten Different Brands Of Open Market Sachet Water Analyzed And The Different Bacterium/ Bacteria Isolated From Each Brand Is Presented In Table 3 Below. Plate Count Method Was Used To Analyze The Total Bacteria Count Of Each Sachet Water Sample. The Samples Were Plated From Stock (In Which Sample Plotted Was Collected Directly From Packaged Sachet Water) And From Two Different Serial Dilutions, Serial Dilution $10^{-1}$ And $10^{-2}$. The Mean Total Bacteria Count Ranges From 4cfu/Ml To $13 \mathrm{cfu} / \mathrm{Ml}$ For Stock, 2cfu/Ml To 9.5cfu/Ml For Serial Dilution $10^{-1}$ And $5.5 \mathrm{cfu} / \mathrm{Ml}$ To None In Serial Dilution $10^{-2}$. A Total Of Six Bacteria Were Isolated From The Sachet Water Vended In Nnewi. The Isolates Were Identified To Be Staphylococcus Epidermidis, Staphylococcus Aureus, Enterobacteraerogenes, Bacillus Subtilis, Proteus Mirabilis And Pseudomonas Aeruginosa. Staphylococcus Aureus Has The Highest Occurrence As It Was Isolated From Four Different Brands (Samples A, D, I And J) Of Sachet Water.

Table 4 Below Shows The Morphological And Biochemical Identification Of Various Isolates From The Water Sample.

Table 5 Below Shows The Parasitological Analysis Of Ten Different Sachet Water Samples. Nine Brands (90\%) Tested Negative For The Presence Of Protozoa, While Cyst Of Entamoeba Coli Was Detected In One Brand (Sample A) Of Sachet Water Samples Analyzed.

The Total Coliform Was Nil For All Samples. This Conforms To The WHO's Guideline Of, No Total Coliforms Or E. Coli Should Be Detected For Every 100ml Of Drinking Water Tested.

The Total Fungal Count Was Also Nil For All Samples, Indicating That No Fungal Colony Was Identified During The Period Of The Culture.

Table 1: Summary Of Peoples' Perception To Reaction Upon Consumption Of Sachet Water

\begin{tabular}{|c|c|c|c|c|c|c|c|c|c|c|c|c|c|}
\hline & \multirow{2}{*}{$\begin{array}{l}\text { TOTAL } \\
\text { NUMBER } \\
\text { PERSONS }\end{array}$} & \multirow{2}{*}{ OF } & \multicolumn{7}{|c|}{ SYMPTOM } & \multicolumn{4}{|c|}{ ACTION TAKEN } \\
\hline & & & $\begin{array}{l}\text { Sto } \\
\text { mac } \\
h \\
\text { Ups } \\
\text { et }\end{array}$ & $\begin{array}{l}\text { Los } \\
s \\
\text { Of } \\
\text { Ap } \\
\text { pet } \\
\text { ite }\end{array}$ & $\begin{array}{l}\text { Vom } \\
\text { iting }\end{array}$ & $\begin{array}{l}\mathrm{Na} \\
\text { use } \\
\mathrm{a}\end{array}$ & $\begin{array}{l}\text { Irri } \\
\text { tati } \\
\text { on }\end{array}$ & $\begin{array}{l}\text { Run } \\
\text { ny } \\
\text { Sto } \\
\text { mac } \\
\text { h }\end{array}$ & $\begin{array}{l}\text { Gener } \\
\text { alized } \\
\text { Abdo } \\
\text { minal } \\
\text { Pain }\end{array}$ & $\begin{array}{l}\text { Noth } \\
\text { ing }\end{array}$ & $\begin{array}{l}\text { Stop } \\
\text { Drinkin } \\
\text { g The } \\
\text { Sachet } \\
\text { Water }\end{array}$ & $\begin{array}{l}\text { Self } \\
\text { Medic } \\
\text { ation }\end{array}$ & $\begin{array}{l}\text { Hospitaliz } \\
\text { ation }\end{array}$ \\
\hline $\begin{array}{l}\text { Number Of } \\
\text { Persons That } \\
\text { Experienced } \\
\text { Symptoms On } \\
\text { Consumption Of } \\
\text { Sachet Water }\end{array}$ & 29 & & 18 & 2 & 1 & 3 & 3 & 1 & 1 & 18 & 4 & 6 & 1 \\
\hline $\begin{array}{l}\text { Number Of } \\
\text { Persons That Do } \\
\text { Not Experience } \\
\text { Symptoms On } \\
\text { Consumption Of } \\
\text { Sachet Water }\end{array}$ & 71 & & Nil & Nil & Nil & Nil & Nil & Nil & Nil & Nil & Nil & Nil & Nil \\
\hline
\end{tabular}


Evaluation of Microbial and Elemental contaminants of Open Market Sachet Water in Nnewi Metropolis

TABLE 2: The Aesthetic Quality And The Concentration Of Mercury, Lead And Calcium In Open Market Sachet Water

\begin{tabular}{|c|c|c|c|c|c|c|}
\hline Samples & Mercury & Lead & Calcium & Colour & Odour & Taste \\
\hline Water Sample (A) & 7.772 & 0.247 & 0.004 & Colourless & Odourless & Tasteless \\
\hline Water Sample (B) & 5.898 & 0.728 & 0.029 & Colourless & Odourless & Tasteless \\
\hline Water Sample (C) & 3.092 & 0.327 & 0.019 & Colourless & Odourless & Tasteless \\
\hline Water Sample (D) & 6.424 & 0.853 & 0.008 & Colourless & Odourless & Tasteless \\
\hline Water Sample (E) & 7.023 & 0.704 & 0.704 & Colourless & Odourless & Tasteless \\
\hline Water Sample (F) & 0.00 & 0.390 & 0.00 & Colourless & Odourless & Tasteless \\
\hline Water Sample (G) & 0.655 & 0.529 & 0.013 & Colourless & Odourless & Tasteless \\
\hline Water Sample (H) & 0.00 & 0.687 & 0.043 & Colourless & Odourless & Tasteless \\
\hline Water Sample (I) & 0.00 & 0.557 & 0.026 & Colourless & Odourless & Tasteless \\
\hline Water Sample (J) & 0.00 & 1.018 & 0.00 & Colourless & Odourless & Tasteless \\
\hline
\end{tabular}

Values $=$ Mean \pm Standard Deviation

$1 \mathrm{ppm}=1 \mathrm{mg} / \mathrm{L}$

WHO Standard For Maximum Allowable Limits

Lead $=0.01 \mathrm{mg} / \mathrm{L}$

Mercury $=0.006 \mathrm{mg} / \mathrm{L}$

Calcium $=<121 \mathrm{mg} / \mathrm{L}(>121 \mathrm{mg} / \mathrm{L}$ Indicates Hard Water $)$

Microbiological Parameter

Table 3: Total Bacterial Count

\begin{tabular}{|c|c|c|c|c|c|}
\hline & & Stock & $10^{-1} \quad$ (Plate & $10^{-2}$ & \multirow[t]{3}{*}{ Suspected Isolates } \\
\hline & & & \multicolumn{2}{|l|}{ Count) } & \\
\hline$S / N$ & Sample & $\begin{array}{l}\text { Mean } \\
\text { (TBC) }\end{array}$ & Mean (TBC) & Mean (TBC) & \\
\hline 1 & Water Sample (A) & 12 & 7.5 & 5.5 & $\begin{array}{l}\text { Staphylococcus } \\
\text { Epidermidis, } \\
\text { Staphylococcus } \\
\text { Aureus. }\end{array}$ \\
\hline 2 & Water Sample (B) & 13 & 9.5 & 4 & $\begin{array}{l}\text { Staphylococcus } \\
\text { Epidermidis, } \\
\text { Pseudomonas } \\
\text { Aeruginosa. }\end{array}$ \\
\hline 3 & Water Sample (C) & 7 & 6 & 2 & Enterobacteraerogenes. \\
\hline 4 & Water Sample (D) & 6.5 & 5 & 1 & $\begin{array}{l}\text { Staphylococcus } \\
\text { Aureus, } \\
\text { Bacillus Subtilis. }\end{array}$ \\
\hline 5 & Water Sample (E) & 5 & 6 & - & $\begin{array}{l}\text { Staphylococcus } \\
\text { Epidermidis. }\end{array}$ \\
\hline 6 & Water Sample (F) & 7.5 & 5 & 2 & Proteus Mirabilis. \\
\hline 7 & Water Sample (G) & 11 & 4 & 1 & $\begin{array}{l}\text { Pseudomonas } \\
\text { Aeruginosa. }\end{array}$ \\
\hline 8 & Water Sample (H) & 4 & 2 & - & Enterobacteraerogenes. \\
\hline 9 & Water Sample (I) & 7.5 & 3 & 1 & $\begin{array}{l}\text { Staphylococcus } \\
\text { Aureus. }\end{array}$ \\
\hline 10 & Water Sample (J) & 7 & 3.5 & 2 & $\begin{array}{l}\text { Staphylococcus } \\
\text { Aureus, } \\
\text { Proteus Mirabilis. }\end{array}$ \\
\hline
\end{tabular}




\section{Evaluation of Microbial and Elemental contaminants of Open Market Sachet Water in Nnewi Metropolis}

Table 4: Morphological and Biochemical Identifications of the Various Isolates from the Water Samples.

\begin{tabular}{|c|c|c|c|c|c|c|}
\hline ISOLATES & A & B & $\mathbf{C}$ & D & $\mathbf{E}$ & $\mathbf{F}$ \\
\hline Form & Circular & Circular & Circular & Circular & Circular & Circular \\
\hline Surface & Smooth & Smooth & Shiny & Smooth & Glistening & Smooth \\
\hline Colour & White & Yellowish & White & Cream & Cream & Whitish \\
\hline Margin & Irregular & Entire & Entire & Undulate & Entire & Entire \\
\hline Elevation & Flat & Raised & Convex & Raised & Raised & Convex \\
\hline Appearance & Rough & Opaque & Moist & Opaque & Transparent & Translucent \\
\hline Gram Reaction & + & + & - & + & - & - \\
\hline Catalyse Test & + & + & + & + & + & + \\
\hline Motility Test & - & + & + & + & + & + \\
\hline Indole Test & - & - & - & - & - & - \\
\hline $\begin{array}{l}\text { Methyl-Red } \\
\text { Test }\end{array}$ & - & + & - & - & + & - \\
\hline $\begin{array}{l}\text { Voges- } \\
\text { Proskauer Test }\end{array}$ & - & - & + & + & + & - \\
\hline $\begin{array}{l}\text { Citrate- } \\
\text { Utilization Test }\end{array}$ & - & - & + & + & + & + \\
\hline $\begin{array}{l}\text { Lactose } \\
\text { Fermentation }\end{array}$ & + & + & + & - & - & - \\
\hline $\begin{array}{l}\text { Glucose } \\
\text { Fermentation }\end{array}$ & + & + & + & + & + & - \\
\hline $\begin{array}{l}\text { Sucrose } \\
\text { Fermentation }\end{array}$ & + & + & + & + & + & - \\
\hline $\begin{array}{l}\text { Frutose } \\
\text { Fermentation }\end{array}$ & + & + & + & + & - & - \\
\hline $\begin{array}{l}\text { Maltose } \\
\text { Fermentation }\end{array}$ & + & + & + & + & + & - \\
\hline Identity & $\begin{array}{l}\text { Staphylococcus } \\
\text { Epidermis }\end{array}$ & $\begin{array}{l}\text { Staphylococcus } \\
\text { Aureus }\end{array}$ & $\begin{array}{l}\text { Enterobacter } \\
\text { aerogenes }\end{array}$ & $\begin{array}{l}\text { Bacillus } \\
\text { Subtilis }\end{array}$ & $\begin{array}{l}\text { Proteus } \\
\text { Mirabilis }\end{array}$ & $\begin{array}{l}\text { Pseudomonas } \\
\text { Aeruginosa }\end{array}$ \\
\hline
\end{tabular}

Key:+: Positive - : Negative

Table 5: Parasitological Analysis of Sachet Water

\begin{tabular}{lll}
\hline S/N & Samples & Result \\
\hline $\mathbf{1}$ & Water Sample (A) & Cyst Of Entamoeba Coli Seen \\
$\mathbf{2}$ & Water Sample (B) & No Parasite Seen \\
$\mathbf{3}$ & Water Sample (C) & No Parasite Seen \\
$\mathbf{4}$ & Water Sample (D) & No Parasite Seen \\
$\mathbf{5}$ & Water Sample (E) & No Parasite Seen \\
$\mathbf{6}$ & Water Sample (F) & No Parasite Seen \\
$\mathbf{7}$ & Water Sample (G) & No Parasite Seen \\
$\mathbf{8}$ & Water Sample (H) & No Parasite Seen \\
$\mathbf{9}$ & Water Sample (I) & No Parasite Seen \\
$\mathbf{1 0}$ & Water Sample (J) & No Parasite Seen \\
\hline
\end{tabular}

\section{DISCUSSION}

This study is a human interest environmental physiology monitoring and reporting. The choice of our investigation stems from commonly reported reactions by human subjects upon consumption of sachet water, which suggested that these sachet waters may not be completely sterile; it may not be entirely free of all infectious microorganisms and there might also be an unsafe 


\section{Evaluation of Microbial and Elemental contaminants of Open Market Sachet Water in Nnewi Metropolis}

level of harmful elements in these sachet waters. When water is of poor quality, it can affect our health and eventually the human life. The health risks associated with consuming contaminated drinking water are of public health concern. According to Akunyili et al., [14] the question that still remains is: how pure is our "pure water"? In this study, we sought to determine people's perception of reaction upon consumption of sachet water and also determine the levels of elements and presence of microbial contaminants in open market sachet water sold in Nnewi, Anambra State, Nigeria.

The observation that $29 \%$ of the study population experienced reactions or symptoms of consumption of different brands of sachet water, questions the safety and portability of the sachet waters in our market. This suggests that there is presence of contaminant(s) in the sachet water, which some people are reacting to. This prompted us into examining the sachet water in our market.

The findings that $60 \%$ (6) of the studied samples had Mercury levels exceeding the WHOs' maximum contaminant level of $0.006 \mathrm{mg} / \mathrm{L}$ and all the samples had Lead levels exceeding the WHOs' maximum contaminant level of $0.01 \mathrm{mg} / \mathrm{L}$ are thought provoking. These findings are of great concern because of the increased epidemiologic and experimental evidence of the adverse health effects of Lead and Mercury at successively lower levels. [15] In 2004 the Joint FAO/WHO expert committee on food additives (JECFA) established a tolerable intake of $1.6 \mu \mathrm{g} / \mathrm{kg}(0.0016 \mathrm{mg} / \mathrm{kg})$ body weight per week for Methyl mercury in order to protect the developing fetus from the neurotoxic effects. [16] Amongst three forms of Mercury, the organic form is most toxic as it passes the blood brain barrier owing to its lipid solubility. Inorganic forms of Mercury cause spontaneous abortion, congenital malformation and Gastrointestinal disorders (like corrosive esophagitis and hematochezia). Poisoning by its organic forms, presents with erethism, acrodynia, gingivitis, stomatitis, neurological disorders, the total damage to the brain and central nervous system, and are also associated with congenital malformation. [17]

In 1993, the Food and Agriculture Organization/WHO established a provisional tolerable weekly intake of $25 \mu \mathrm{g}$ Lead/kg body weight in humans. The level of Lead in drinking water is of prime concern because plumbism (chronic Lead poisoning) has also been associated with reduced gestational age and birth weight, as well as hypertension, lower hemoglobin levels, and impairment of renal function, among other effects. [18]

The entire open market sachet water samples analyzed were colourless, odourless, tasteless and therefore conforms to the aesthetic quality of drinking water as stated by WHO. The calcium level of all the sachet water analyzed ranges from 0 to $0.704 \mathrm{mg} / \mathrm{L}$ indicating that all is soft water.

According to the WHO guidelines for drinking water quality, [19] safe drinking water should not contain "total" Coliforms, Escherichia coli or any "thermo tolerant" Coliforms in a $100 \mathrm{ml}$ water sample. Total Coliforms and Escherichia coli are used as indicators to measure the degree of pollution, sanitary quality and microbial safety of drinking water, because testing for all known pathogens is a complicated and expensive process. Total coliform bacteria are not likely to cause illness, but their presence indicates that the water supply may be vulnerable to contamination by more harmful microorganisms. Going by the zero tolerance levels stipulated by regulatory agencies for Coliforms in drinking water, all the sachet water analyzed met the standards of quality water. This is in line with the findings of Egwari et al. [20] in Lagos southwest Nigeria who in their bacteriology study of sachet water found no enteric pathogens or Escherichia coli to be present.

From this study, the mean total bacteria counts of each sachet water analyzed were between 0cfu/ml to $13 \mathrm{cfu} / \mathrm{ml}$. When found in drinking water, microorganisms constitute a real indicator that it should not be used for human consumption if these contaminants are found in excess of maximum permissible level of $1 \times 10^{2} \mathrm{cfu} / \mathrm{ml}(100 \mathrm{cfu} / \mathrm{ml})$ set by WHO 2008 and other respective standards and guidelines, [21] therefore, the total bacterial counts were within the limit stipulated to be acceptable for potable water. The total bacteria count is used as a measure of the effectiveness of water treatment processes such as coagulation, filtration, and disinfection and as an indication of distillation system cleanliness, rather than for assessing safety or portability. [22] Experience has shown that maintenance of chlorine residual cannot be relied upon to totally prevent the occurrence of bacteria in drinking water. [23] Ridgway and Olson [24] have shown that the majority of viable bacteria in chlorinated drinking water are attached to particles. Presumably, microbes entrapped in particles or adsorbed onto surfaces are shielded from disinfection and are not inactivated. Several investigators have reported the isolation of encapsulated bacteria from chlorinated drinking water. [25] They concluded that production of the extracellular capsule helps to protect bacteria from chlorine. However, only circumstantial evidence was given to support these conclusions.

This study recorded the occurrence of bacteria in all the sachet-water samples analyzed. Ideally, potable water should not contain any pathogenic bacteria. [26] Most of the bacteria detected were pathogenic microorganism. The presence of pathogenic bacteria in water packaged for drinking purposes has been previously documented in the literature. [27] Microbial contamination of treated and packaged water is due to several factors that contribute to failure of the treatment process. They include poor hygienic conditions of the handlers, presence of biofilms on processing surfaces due to poor cleaning and sanitation 


\section{Evaluation of Microbial and Elemental contaminants of Open Market Sachet Water in Nnewi Metropolis}

and packaging of treated water under unhygienic conditions. [28] The bacteria characterized and identified from the sachet water samples were found most to be opportunistic pathogens which are usually isolated from unhygienic environments or materials. [29] The predominant once include Staphylococcus aureus, Proteus mirabilis, Pseudomonas aeruginosa, Bacillus subtilis and Staphylococcus epidermidis. Reports on studies of sachet water from different locations recorded the occurrence of these bacteria. Oluwafemi and Oluwole [30] encountered Proteus mirabilis, Staphyloccocus aureus, and Bacillus subtilis, in their study of microbiological examination of sachet water due to a cholera outbreak in Ibadan, Nigeria. These microorganisms are versatile in their nutrient requirements and can survive with limited nutrient availability. Most of these bacteria are indigenous to aquatic environments. [31] Pseudomonas species are well known indicators of potential bacterial re-growth in nutrient limited environments such as channels of water distribution systems. [32] The ingestion of water contaminated with these bacteria may pose a potential health risk to the immune compromised members of the population, especially the sick, newborn babies and elderly people. [33] Staphylococcus aureus has the highest occurrence as it was isolated from four different samples (samples A, D, I and J) of sachet water analyzed. Staphylococcus aureus is known to produce enterotoxin, [34] the pathogenic strains of Staphylococcus aureus, often promote infections by producing virulence factors such as potent protein toxins, and the expression of a cell-surface protein that binds and inactivates antibodies. The level of mean total bacteria count between (zero) $0 \mathrm{cfu} / \mathrm{ml}$ to $13 \mathrm{cfu} / \mathrm{ml}$ suggests that the treatment technique applied to the analyzed sachet waters is probably effective enough to eliminate bacteria to the level that does not pose acute health risk to healthy consumers, but the ingestion of these bacteria with contaminated water may pose a potential health risks to the immune compromised members of the population.

In this study, the cyst of Entamoeba coli was detected in one sample (sample A) of sachet water samples analyzed. Entamoeba coli are non-pathogenic species of entamoba that frequently exist as a commensal parasite in the human gastrointestinal tract. Entamoeba coli are mostly harmless parasitic, and do not cause harm to the host. However, there are rare cases of internal bleeding and this may lead to intestinal lesions. The contamination of this brand of sachet water with Entamoeba coli suggests contamination of the water either through improper sanitization or sterilization of the factory equipment or instrument used in the production processes. It can also result from the use of unsterile polyethylene which is used for the packaging of the water product or improper handling of the packaging material by the workers.

\section{CONCLUSIONS}

The contamination of drinking water poses a serious health risk to humans since water is one of the most vital ingredients for human survival. The importance of access to good quality water cannot be overemphasized. Our observation shows that even though all the sachet water analyzed conform to the WHO's guideline of, no total Coliforms or Escherichia coli should be detected for every $100 \mathrm{ml}$ of drinking water tested, there are still presences of microorganisms which may pose public health risks to the immune compromised members of the population. Our observations also show that most sachet waters sold in Nnewi are contaminated by heavy metals such as Lead and Mercury. Our studies have been able to establish that some of the sachet water being sold in Nnewi, Anambra State, Nigeria are below standards as per Mercury and Lead content making them unsafe for human consumption.

These findings suggest that consumers of sachet water could be at potential health risk posed by possible bioaccumulation, magnification and gradual poisoning. Hence, there is a need for the intervention of relevant government health agencies like NAFDAC and other stakeholders to intensify surveillance activities and enforce stringent hygienic measures to sachet water industries and retail outlets.

\section{Conflicts of Interest Statement}

The authors declare that the research was conducted in the absence of any commercial or financial relationships that could be construed as a potential conflicts of interest.

\section{REFERENCES}

1) Elemile OO, Raphael DO, Omole DO, Oloruntoba EO, Ajayi EO, Ohwavborua NA. Assessment of the impact of abattoir effluent on the quality of groundwater in a residential area of Omu-Aran, Nigeria. Environ Sci Eur. 2019; 31:16.

2) Fisher MB, Williams AR, Jalloh MF, Saquee G, Bain RES, Bartram JK. Microbiological and Chemical Quality of Packaged Sachet Water and Household Stored Drinking Water in Freetown, Sierra Leone. PLOS ONE 2015; 10(7): e0131772. doi:10.1371/ journal.pone.0131772

3) United Nations Economic and Social Council (Ecosoc). Progress towards the Sustainable Development Goals: report of the secretary general. 1-20. 2017 Available at 


\section{Evaluation of Microbial and Elemental contaminants of Open Market Sachet Water in Nnewi Metropolis}

http://admin.indiaenvironmentportal.org.in/files/file/Progress\%20towards\%20the\%20Sustainable\%20Development\%2 0Goals_0.pdf (accessed 6 November 2020).

4) Sawyerr HO, Adedotun AT, Abiodun SA, Salami OO. Impact of dumpsites on the quality of soil and groundwater in satellite towns of the Federal Capital Territory, Abuja, Nigeria. J Health Pollut. 2017; 7(14):15-21.

5) Wright J, Dzodzomenyo M, Wardrop NA, Johnston R, Hill A, Aryeetey G et al. Effects of sachet water consumption on exposure to microbe-contaminated drinking water: household survey evidence from Ghana. Int. J. Environ. Res. Public Health, 2016; 13:303; doi:10.3390/ijerph13030303

6) Ogundipe SS. Safe Water: So near, yet so far. Vanguard Newspapers Saturday September 13, 2008. (Home Education) Section C (Col. 9 and 10):15. 2008.

7) Omole DO, Ndambuki JM Balogun K. Consumption of sachet water in Nigeria: quality, public health and economic perspectives. African J. Sci. Technol. Innov. 2015; 7:1:45-51.

8) National Population Commission, NPC (2006). Nigerian Population Census report 2006.

9) Yakassai IA. Analysis and Production of Packaged Water. Nigeria: Pressma Printing and Publications; 2009: 30-41.

10) APHA. Standard Methods for the Examination of Water and Waste Water 21st edn. Washington, DC: American Public Health Association; 2005.

11) Chessbrough M. Medical Laboratory Manual for Tropical Countries $4^{\text {th }}$ Edn. Cambridge: Cambridge University Press; 2004: 143-167.

12) Bergey, D.H. 1860-1937 and John G. Holt $9^{\text {th }}$ ed. Bergey's Manual of Determinative Bacteriology. Philadelphia: Lippincott Williams \& Wilkins; 2000.

13) Okwa OO, Gbadamosi ZO. Parasitological evaluation of sachet drinking water in areas of Lagos state. Electron J Biol. 2017; 13(2): 144-151

14) Akunyili D, Cockburn R, Newton PN, Agyarko EK, White NJ. The global threat of counterfeit drugs: why industry and government must communicate the danger. PLoS Med 2005; 2(4): e100.

15) Davis JM, Elias RW, Grant LD. Current issues in human Lead exposure and regulation of Lead. Neurotoxicol. 1993; 14:15-27.

16) JECFA. Methyl Mercury. In: Safety evaluation of certain food additives and contaminants. Report of the 61st Joint FAO/WHO Expert Committee on Food Additives. Geneva, WHO: International Programme on Chemical Safety, WHO Technical Report Series 922; 2004: 132-139.

17) Lenntech Water Treatment and Air Purification. Water Treatment. Lenntech, Rotterdamseweg; 2004.

18) Vupputuri S, He J, Muntner P, Bazzano LA, Whelton PK, Batuman V. Blood Lead level is associated with elevated blood pressure in blacks. Hypertens. 2003; 41:463-468.

19) World Health Organization (WHO). Guidelines for Drinking-Water Quality. $4^{\text {th }}$ Edn. Geneva: World Health Organization; 2011: 104-108.

20) Egwari LO, Iwuanyanwu S, Ojelabi Cl, Uzochukwu O, Effiok WW. Bacteriology of sachet water sold in Lagos, Nigeria. East Frica Med J. 2005; 85(2):235-40.

21) Abdelmonem M, Abdella HM, Abdel-Magid, Yahia NA. Accessement of drinking water microbial contamination in ALButana region of Sudan. J Appl. Sci. 2012; 12:856-862.

22) Reasoner DJ, Geldreich EE. A new medium for the enumeration and subculture of bacteria From potable water. Appl. Environ. Microbiol. 1985; 49(1):7

23) Le Chevallier MW, Babcock TM, Lee RG. Examination and characterization of distribution system biofilms. Appl. Environ. Microbiol. 1987; 53:2714-24.

24) Ridgway HF, Olson BH. Chlorine resistance patterns of bacteria from two drinking water distribution systems. 1982; 44:972-87.

25) Clark TF. Chlorine tolerant bacteria in a water distribution system. Public Works 1984; 115:65-67.

26) NAFDAC. Guidelines for Production and Registration of Packaged Water: New guidelines and regulations. Abuja: National Agency for Food and Drug Administration and Control, NAFDAC; 2004: 1-10.

27) Oluyege JO, Olowomofe TO, Abiodun OR. Microbial contamination of packaged drinking water in Ado-Ekiti Metropolis, South Western Nigeria. Am. J Res. Commun. 2014; 2(10): 231-246.

28) Ollos PJ, Huck PM, Slawson RM. Factors affecting biofilm accumulation in model distribution systems. J Am. Water Works Assoc. 2003; 95: 87-97. 


\section{Evaluation of Microbial and Elemental contaminants of Open Market Sachet Water in Nnewi Metropolis}

29) Bitton G. Waste Water Microbiology 3rd Edition. Wiley Series in Ecological and Applied Microbiology; 2005. ISBN 0471650714(2).4.pdf.

30) Oluwafemi F, Oluwole ME. Microbiological Examination of Sachet Water Due to aCholera Outbreak in Ibadan, Nigeria. Open J Med. Microbiol. 2012; 2:115-120.

31) Berger PS, Oshiro RK. Source Water Protection: Microbiology of Source Water. In: G. Bitton, Eds. Encyclopedia of Environmental Microbiology. New York: Wiley Inter Science; 2002: 2967-2978.

32) Ribas F, Perramon J, Terradillos A, Frias J, Lucena F. The Pseudomonas group as an indicator of potential regrowth in water distribution systems. J Appl. Microbiol. 2000; 88: 704-710.

33) Le Chevallier MW, Seidler RJ, Evans TM. Enumeration and characterization of standard plate count bacteria in chlorinated and raw water supplies. Appl. Environ. Microbiol. 1980; 40:922-930.

34) Bennet RW, Lancette GA. Principal and Practice of Infectious Disease. $7^{\text {th }}$ eds. Phiidelphia: Livingstone Elsevier; 1992 : 3495-3526. 